Gut, 1962, 3, 295

\title{
Dynamics of the mucosa of the small intestine in idiopathic steatorrhoea
}

\author{
B. CREAMER
}

From St. Thomas's Hospital Medical School, London

EDITORIAL SYNOPSIS The turnover of cells in the abnormal mucosa of the small intestine of idiopathic steatorrhoea has been studied. Evidence is presented that the abnormal mucosa is the result of a maturation arrest of the epithelial cells.

Idiopathic steatorrhoea, in common with coeliac disease and tropical sprue, is characterized by an abnormal mucosa of the upper small intestine. The striking features of this are the absence or rudimentary character of the villi and the increased depth of the crypts (Shiner, 1957; Shiner and Doniach, 1960). The pathogenesis of this abnormality is unknown but descriptively the term 'atrophy' is widely used.

Any abnormality must be viewed in the light of the dynamic nature of the normal intestinal mucosa. In health the intestinal mucosa is in a constant state of renewal with active proliferation in the crypts from which cells migrate up the villi to be lost at the tips (Leblond and Stevens, 1948). The time taken for complete replacement of the duodenal or jejunal mucosa in experimental animals is variously estimated from 1.6 to 3.0 days (Leblond and Stevens, 1948; McMinn, 1954; Leblond and Messier, 1958; Creamer, Shorter, and Bamforth, 1961) and the only observations in man suggest a renewal time of about two days (Bertalanffy and Nagy, 1961).

METHODS AND MATERIAL

Mitotic counting was performed on the biopsy specimens from eight patients with idiopathic steatorrhoea. These were selected because the biopsy was of sufficient size and well orientated so that at least 2,000 nuclei could be counted. Clinical details of these cases are given in Table I. Six biopsies were obtained with a Shiner tube and two at laparotomy. Only the metaphases were counted as these were easily recognizable while some early prophases and late telophases presented difficulty.

As controls the biopsies from four other patients were used. These had gastrointestinal symptoms but the biopsies appeared histologically normal.

Intestinal cells were labelled in one patient (case 7), who developed advanced ovarian carcinomatosis some months after the first biopsy. A laparotomy was performed for large bowel obstruction exactly 24 hours after the label of $10 \mathrm{mc}$. tritiated thymidine (A.E.R.E., Harwell) had been given through a gastric tube (Rubini, Cronkite, Bond, and Fliedner, 1960). A surgical specimen of jejunum was obtained. Autoradiographs were prepared using Kodak AR 10 stripping film and exposing for three months.

RESULTS

ARCHITECTURE OF THE MUCOSA The abnormal mucosa is composed of loosely packed glands or crypts of about twice the depth seen in normal mucosa (Fig. 1). These open by way of necks or pits onto the surface, which is flat, or bumpy with rudimentary villi. However, in section only about one

TABLE I

CLINICAL DETAILS OF PATIENTS STUDIED

\begin{tabular}{|c|c|c|c|c|c|c|c|}
\hline Case No. & Age (yr.) & $\operatorname{Sex}$ & $\begin{array}{l}\text { Duration of } \\
\text { Symptoms }\end{array}$ & $\begin{array}{l}\text { Coeliac } \\
\text { History }\end{array}$ & $\begin{array}{l}\text { Faecal Fat } \\
(\mathrm{g} .124 \mathrm{hr} .)\end{array}$ & $\begin{array}{l}\text { Exudative } \\
\text { Enteropathy }\end{array}$ & $\begin{array}{l}\text { Clinical State at } \\
\text { Biopsy }\end{array}$ \\
\hline $\begin{array}{l}1 \\
2 \\
3 \\
4 \\
5 \\
6 \\
7 \\
8\end{array}$ & $\begin{array}{l}55 \\
42 \\
35 \\
45 \\
44 \\
58 \\
50 \\
47\end{array}$ & $\begin{array}{l}\mathbf{M} \\
\mathbf{M} \\
\mathbf{F} \\
\mathbf{M} \\
\mathbf{M} \\
\mathbf{F} \\
\mathbf{F} \\
\mathbf{F}\end{array}$ & $\begin{array}{l}2 \text { yr. } \\
9 \text { mth. } \\
2 \text { mth. } \\
44 \mathrm{yr} . \\
2 \text { mth. } \\
21 \mathrm{yr} . \\
9 \mathrm{mth} . \\
15 \mathrm{yr} .\end{array}$ & $\begin{array}{l}- \\
\bar{z} \\
\overline{-} \\
\overline{-} \\
-\end{array}$ & $\begin{array}{l}40.1 \\
12.0 \\
11.4 \\
55 \% \text { intake } \\
89 \% \text { intake } \\
8.2 \\
9.4 \\
7 \cdot 1\end{array}$ & $\begin{array}{l}- \\
\bar{\perp} \\
\overline{+} \\
\overline{-} \\
-\end{array}$ & $\begin{array}{l}\text { Severely ill } \\
\text { Ill, untreated } \\
\text { Ill, untreated } \\
\text { Untreated with diet } \\
\text { Responding to diet } \\
\text { Untreated } \\
\text { Untreated } \\
\text { Well, no diet }\end{array}$ \\
\hline
\end{tabular}




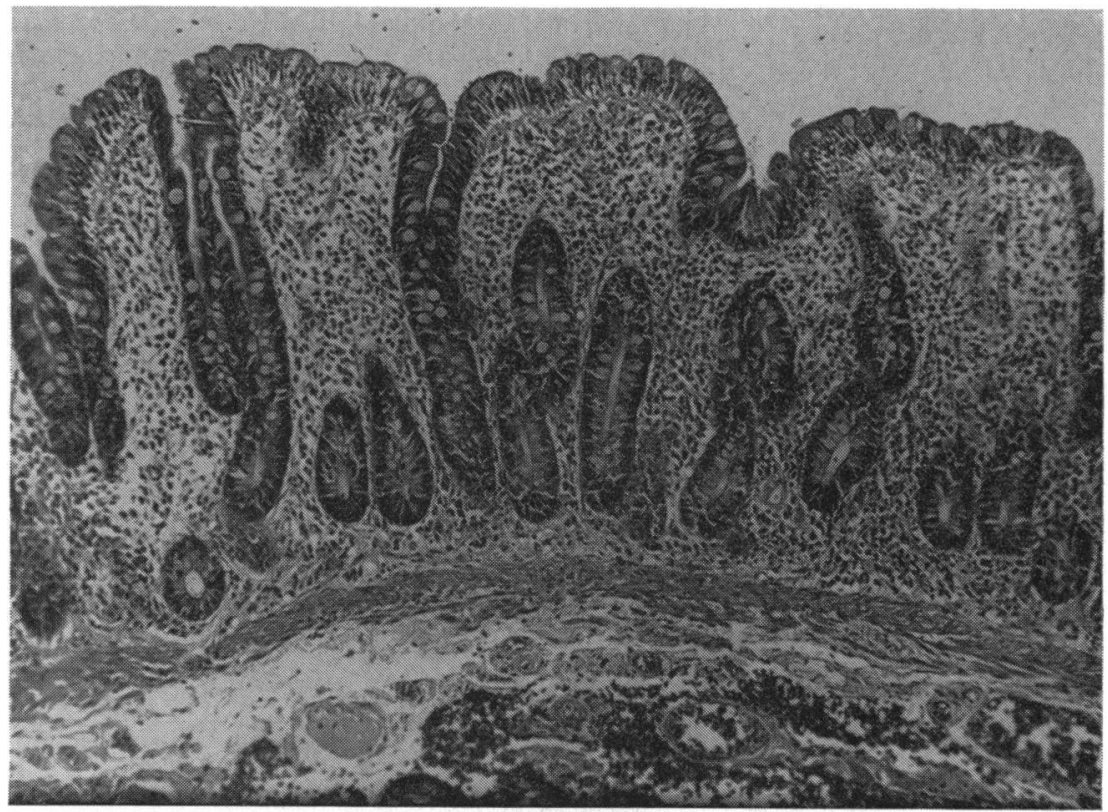

FIG. 1. A section of the abnormal mucosa from case 3. Note that there are few pits opening onto the surface.

FIG. 2. A section of the abnormal mucosa from case 3. Note the branched glands. 

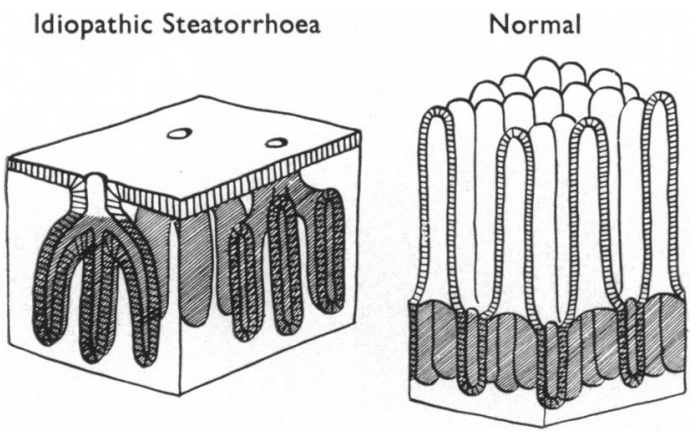

FIG. 3. A diagrammatic representation of the mucosa in idiopathic steatorrhoea and in health. The crypt cells are hatched in. Note the free communication between the crypts and villi in health and the bottleneck in idiopathic steatorrhoea.

crypt in three is seen to open directly onto the surface so that each pit must communicate with several crypts. In fact branched glands are commonly seen (Fig. 2). Allowing for the threedimensional structure of the mucosa it is probable that from three to six crypts join to open onto the surface through a common orifice (Fig. 3).

RELATIVE SIZE OF CELl POPUlation There are two main types of cell that can be distinguished without difficulty. The crypts are lined with immature cells, some of which contain mitotic figures, while the pits and surface are covered by adult cells. The cells covering the surface are irregular and degenerate while those in the pits are more normal in appearance. Goblet cells are sparse in the adult population but common in the crypts where they have been counted in with the crypt cell population. In mitotic counting the numbers of crypt and adult cells are recorded for each specimen (Table II). The ratio between crypt and adult cells in the eight cases, counted in

\section{TABLE II}

MITOTIC COUNTS

\begin{tabular}{lccc}
$\begin{array}{l}\text { Case } \\
\text { No. }\end{array}$ & $\begin{array}{l}\text { Adult : Crypt } \\
\text { Cell Ratio }\end{array}$ & $\begin{array}{l}\text { Metaphases } \\
\text { Per 100 Crypt } \\
\text { Cells }\end{array}$ & $\begin{array}{l}\text { Metaphases } \\
\text { Per 100 Total } \\
\text { Cells }\end{array}$ \\
\hline 1 & $1: 3.8$ & 1.0 & 0.9 \\
2 & $1: 3.7$ & 0.9 & 0.7 \\
3 & $1: 3.0$ & 1.0 & 0.8 \\
4 & $1: 2.1$ & 0.8 & 0.6 \\
5 & $1: 2.7$ & 1.4 & 1.0 \\
6 & $1: 2.1$ & 0.9 & 0.6 \\
7 & $1: 2.2$ & 0.9 & 0.5 \\
8 & $1: 1.3$ & 1.9 & 1.1 \\
Average & $1: 2.6$ & 1.1 & 0.8 \\
Controls & & & 0.5 \\
Average & $2.4: 1$ & 1.9 & $0.4-0.6$ \\
Range & $3.0: 1.2 .0: 1$ & $1.3-2.6$ &
\end{tabular}

one plane, varies between $3 \cdot 8$ and 1.3 to 1 with a mean of 2.6 to 1 . It is difficult to correct for the geometry of the mucosa but it is probable that the crypt cell population exceeds the adult cell population by from two to 16 times.

By comparison the control counts show that in health the ratio is the other way, the adult cell to crypt cells ratio being $2: 4$ to 1 . The three-dimensional structure is such that the adult cell population is at least twice the size of the crypt cell population. Further, in health, the two populations communicate freely with each other. In idiopathic steatorrhoea the architecture of the mucosa reveals a bottleneck, the pits, which are a narrow communicating channel between the large crypt cell population and the smaller adult cell population (Fig. 4).

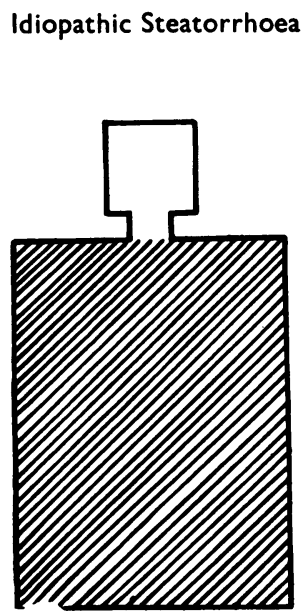

Normal

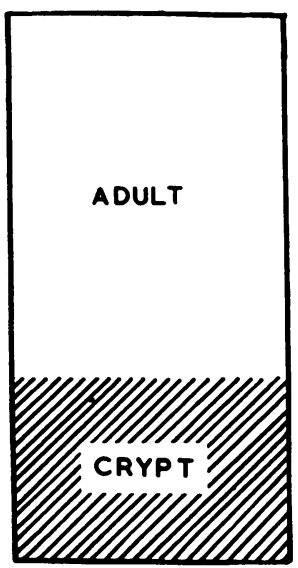

FIG. 4. A diagram of the relative sizes of the cell populations in health and idiopathic steatorrhoea. The bottleneck of the pits is indicated.

MITOTIC ACTIVITY The mitotic activity in the crypts of idiopathic steatorrhoea is relatively less than that seen in the controls (Table II). While some cases show a mitotic rate about half that of the controls there is overlapping between the two series. If mitotic activity is related to the total number of cells it is higher in idiopathic steatorrhoea than in the controls because of the smaller number of adult cells.

MIGRATION OF CELLS In the biopsy which was obtained 24 hours after labelling with tritiated thymidine the mitotic activity in the crypts was $0.8 \%$. This is comparable with the activity in the previous biopsy, $0.9 \%$, and with the rest of the series. Autoradiography showed that many cells within the 


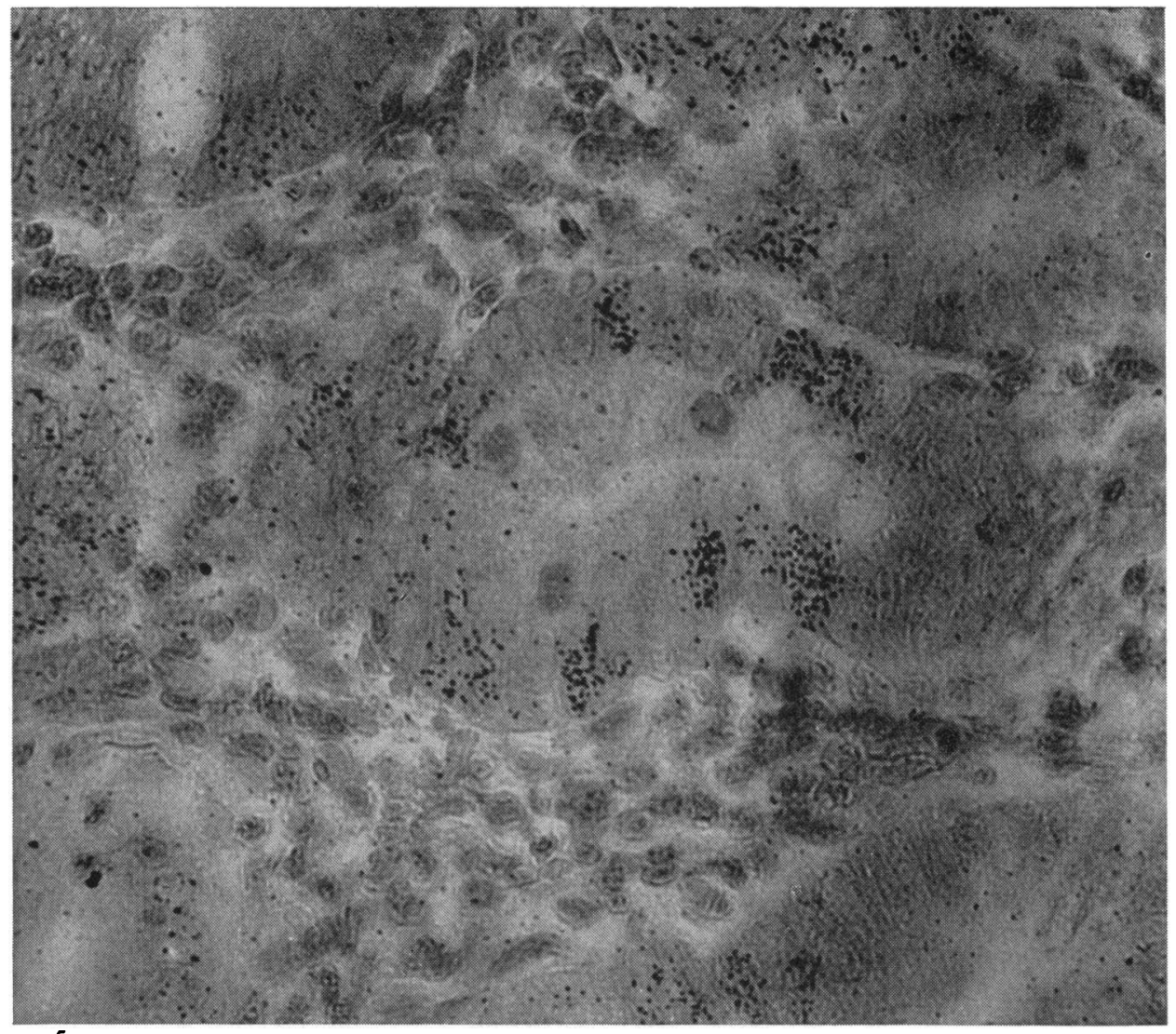

FIG. 5. Auto-

radiograph of

a crypt from

case 7 show-

ing grains

labelling the

nuclei in

groups of

cells. Three

metaphases

are present

but un-

labelled.

FIG. 6. Auto-

radiograph of

two pits from

case 7.

Labelled

cells can be

seen in the

pits but not on

the surface.

FIG 5 .

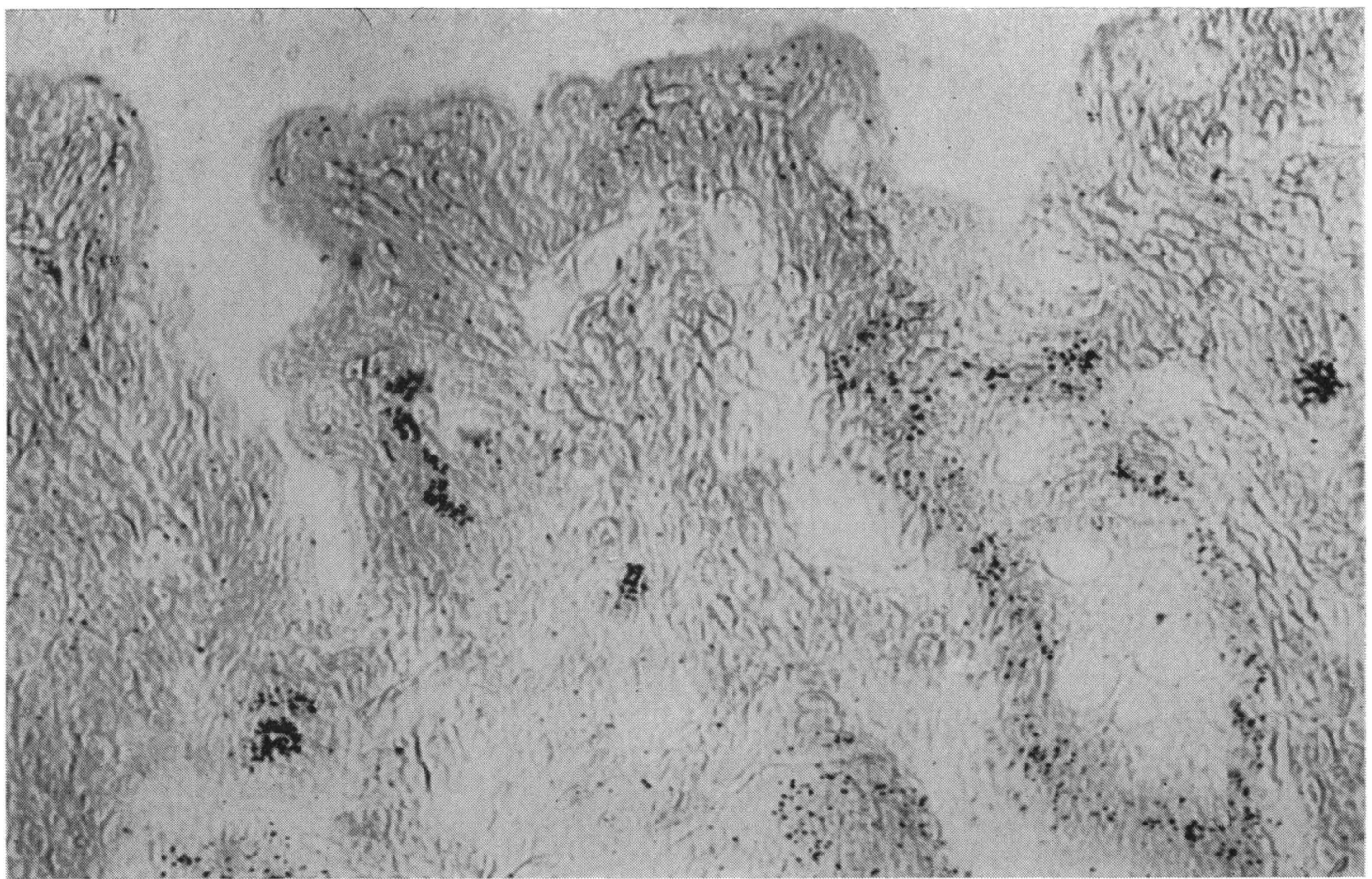

FIG. 6 . 
crypts were labelled. The pattern was that throughout the crypts small groups of two or three cells bore the label separated by similar numbers of unlabelled cells (Fig. 5). Mitotic figures were conspicuous by not showing any label.

Labelled cells were seen lining the necks of crypts but the surface cells were unlabelled (Fig. 6). The extent of the cell migration was therefore only from crypt to neck at 24 hours.

\section{COMMENT}

In idiopathic steatorrhoea there is a large crypt cell population and a small adult population. In health the crypts produce enough cells to replace the adult population in two days, that is, an output of new cells roughly the same size as the crypt population every 24 hours. The abnormal mucosa shows a mitotic activity at least half that of health; this implies that the crypts produce a population half their own size every 24 hours (Fig. 7). This could replace the adult cells many times over yet the observation with labelled cells shows that in 24 hours cells migrate only to the necks and not onto the surface. Only a fraction of the adult cells is replaced in one day. Therefore the majority of newly formed cells can never reach the adult population but die in situ in the crypts. It is probable that this loss is from 70 to $98 \%$ of all newly formed cells. This process seems best explained as a matura-

Idiopathic Steatorrhoea

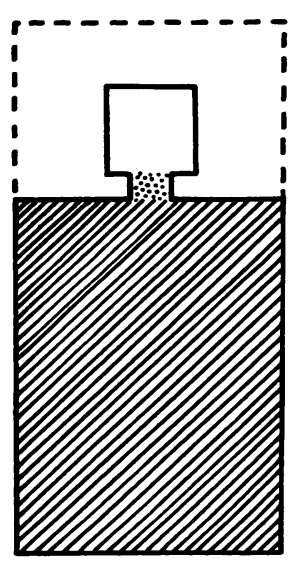

FIG. 7. Diagram showing relative sizes of cell populations and production rate of new cells. The dashed line (24 hours) in health represents the level to which new cells ascend in one day. The dashed line in idiopathic steatorrhoea shows the possible size of the new cells produced in one day if all survived. However, the stippled area in the bottleneck is the actual extent of new cells surviving at one day. tion defect of epithelial cells. Goblet cells appear to mature normally.

\section{CLINICAL CORRELATION}

The degree of maturation defect in a specimen can be assessed by the ratio of crypt cells to adult cells. Where the crypt cell population is large and the adult small the defect is severe and conversely where the adult population is larger and the crypt population smaller the defect is mild. The ratio of crypt to adult cells used here is that counted in one plane; the actual disparity must be larger.

There is a surprisingly good correlation between the degree of defect and the clinical condition of the patient (Table III). The most marked defect was

TABLE III

CORRELATION BETWEEN DEGREE OF DEFECT AND CLINICAL STATE

\begin{tabular}{lllc}
$\begin{array}{l}\text { Case } \\
\text { No. }\end{array}$ & Clinical State & Remarks & $\begin{array}{c}\text { Adult }: \text { Crypt } \\
\text { Cell } \text { Ratio }\end{array}$ \\
\hline 1 & Severely ill & Cachectic & $1: 3 \cdot 8$ \\
2 & Severely ill & & $1: 3 \cdot 7$ \\
3 & Severely ill & Exudative enteropathy & $1: 3 \cdot 0$ \\
4 & Moderately ill & Coeliac history & $1: 2 \cdot 1$ \\
5 & Moderately ill & Exudative enteropathy & $1: 2 \cdot 7$ \\
6 & Moderately ill & & $1: 2 \cdot 1$ \\
7 & Moderately ill & & $1: 2 \cdot 2$ \\
8 & Well & Spontaneous remission & $1: 1 \cdot 3$ \\
& & 12 yr. &
\end{tabular}

found in the most severely ill patient, a cachectic man who failed to respond to all measures, including steroids and a gluten-free diet. The mildest defect was seen in a woman who was in a long and spontaneous remission and was having no drug or dietetic treatment. The highest mitotic activity was seen in this patient and another who was responding excellently to a gluten-free diet.

This assessment of maturation defect was not evident from histological examination without cell counting. Thus case 2 showed 'partial villous atrophy', rudimentary villi, yet had a severe defect, whereas case 8 showed 'subtotal villous atrophy', a flat mucosa, and yet the defect was mild.

\section{DISCUSSION}

There have been two previous reports containing figures for mitotic counting in idiopathic steatorrhoea (Shiner and Doniach, 1960; Padykula, Strauss, Ladman, and Gardner, 1961). There is no detailed agreement between the figures in these two papers and in the present observations. There seem to be two main causes for disagreement. First the recognition of mitotic figures can cause difficulty, 
particularly early prophase or late telophase. Secondly, the present results suggest that the mitotic rate is higher in clinical remission and therefore selection of cases may influence the figures.

The concept advanced here is that the abnormal mucosa is the result of a maturation arrest of epithelial cells. Only between $2 \%$ and $30 \%$ of the cells produced in the crypts survive and enter the adult population; the rest die in situ. The adult cell population is therefore fed by a trickle of cells and despite its small size is replaced more slowly than in health. The normal life of an adult cell is two days but it is probable that in idiopathic steatorrhoea the life may be more than doubled. This helps to explain the abnormality of the surface cells, for not only are they imperfectly formed but senile.

The architecture of the mucosa is the result of maturation arrest. The crypts are deep because of the increased mass of dividing cells and join together in the bottleneck of the pits because the output of cells is small and villi are absent because there is not a sufficient adult cell population to cover them. The pattern of labelled cells in the crypts suggests an increased number of stem cells, each of which divides fewer times than in health. The maturation defect probably affects cells one or two divisions removed from the stem cell. Goblet cells may mature at an earlier generation than epithelial cells and therefore escape the arrest.

The degree of maturation defect seems to correlate well with the clinical condition though larger numbers of cases will be needed before this can be accepted. By analogy it seems likely that the maturation defect is due to a deficiency but the present study gives no clue as to what is lacking.

The term 'atrophy' is widely used and characterizes the loss of villi. However, it gives a totally erroneous impression of the basic mechanism. It is suggested that the idea of mucosal maturation arrest is more appropriate.

\section{SUMMARY}

The turnover of epithelial cells in the abnormal small intestinal mucosa of idiopathic steatorrhoea has been studied in eight patients. There is a profound disturbance of the normal dynamics. The crypt cell population is much larger than in health and the adult cell population much smaller. The mitotic rate is rather less than normal but sufficient to replace the adult cell population several times a day if all the new cells matured. However, labelled cells, studied in one case only, migrate only a very short distance in $\mathbf{2 4}$ hours so that the vast majority of the new cells die in situ in the crypts. This is a maturation arrest of the intestinal epithelial cells of which the architecture of the abnormal mucosa is the result.

I wish to thank Professor R. Curran for constant help and encouragement and for the photomicrographs. I also wish to thank Sir John Richardson for permission to study case 7 and Dr. R. D. Bradley for help.

\section{REFERENCES}

Bertalanffy, F. D., and Nagy, K. P. (1961). Mitotic activity and renewal rate of the epithelial cells of human duodenum. Acta anat. (Basel), 45, 362-370.

Creamer, B., Shorter, R. G., and Bamforth, J. (1961). The turnover and shedding of epithelial cells. Gut, 2, 110-118.

Leblond, C. P., and Messier, B. (1958). Renewal of chief cells and goblet cells in the small intestine as shown by radioautography after injection of thymidine- $\mathrm{H}^{3}$ into mice. Anat. Rec., 132, 247-259.

_- and Stevens, C. E. (1948). The constant renewal of the intestinal epithelium in the albino rat. Ibid., 100, 357-377.

McMinn, R. M. H. (1954). The rate of renewal of intestinal epithelium in the cat. J. Anat. (Lond.), 88, 527-532.

Padykula, H. A., Strauss, E. W., Ladman, A. J., and Gardner, F. H. (1961). A morphologic and histochemical analysis of the human jejunal epithelium in nontropical sprue. Gastroenterology, 40, 735-765.

Rubini, J. R., Cronkite, E. P., Bond, V. P., and Fliedner, T. M. (1960). The metabolism and fate of titrated thymidine in man. J. clin. Invest., 39, 909-918.

Shiner, M. (1957). Small intestinal biopsies by the oral route. J. Mt. Sinal Hosp., 24, 273-285.

-, and Doniach, I. (1960). Histopathologic studies in steatorrhea. Gastroenterology, 38, 419-440. 